\title{
A Close Connection between the Disciplines of Industrial Organization and Finance: A Worthy Objective or a Bridge Too Far?
}

\author{
Lawrence J. White \\ Stern School of Business \\ New York University \\ Lwhite@stern.nyu.edu \\ Prepared for the \\ International Journal of the Economics of Business
}

\begin{abstract}
$\underline{\text { Abstract }}$
Periodically the question of whether there ought to be a substantially closer connection between the disciplines of industrial organization (IO) and finance has been a topic of conversation within the IO discipline. After documenting three such initiatives that ultimately failed to have lasting effects, this article argues that a goal of a close interweaving of IO and finance is a chimera - but that more modest interactions have been and continue to be possible.
\end{abstract}

Key words: Industrial organization; finance; capital asset pricing model (CAPM); Tobin’s Q; event studies

JEL codes: B40; G00; L00 


\section{Introduction}

Periodically during my professional career as an economist - which now spans over four decades - the question of whether there ought to be a close - or at least, a substantially closer connection between the disciplines of industrial organization (IO) and finance has been a topic of conversation within the IO field. Although both disciplines could be considered to be part of the broader area of business economics, both are largely separate from each other.

Usually, the discussion about a closer connection takes the form of a vague hope that IO economists ought somehow to be able to take more of what is being addressed in finance and incorporate those concepts into IO analyses - whether theoretical or empirical. I used to have some of these vague hopes myself.

I have now come to the conclusion that this goal of a substantially closer connection is a chimera. I offer that conclusion as someone who has been a practicing IO economist for over 40 years and who has also been a practicing financial economist - at least with respect to financial institutions (especially depository and mortgage-related institutions) and their regulation - for over 25 years. In support of this position I will discuss the three initiatives of which I am aware that seemed to offer the promise of some integration of IO and finance; in the end, all three turned out to be blind alleys. In addition I will offer some thoughts about why inherently this goal would be a difficult one at best and probably not worth the effort. However, there are still at least two areas where IO and finance have fruitfully interacted and should continue to do so, which will be discussed in the concluding section.

\section{The three failed initiatives}

The inclusion of risk in profit-concentration empirical studies 
In the 1960s and early 1970s the conceptual basis for modern finance - the capital asset pricing model (CAPM) - was developed and circulated more widely through the economics profession. The important insight from the CAPM was that (in a context where investors would rationally hold a diversified portfolio of assets) the appropriate measure of the riskiness of an asset was the covariance of its returns with the broad market's returns, rather than just the ownvariance of the asset's returns.

The application to the empirical IO of the time was straightforward: Profit-concentration regression studies were then the primary way of testing the structure-conduct performance (S-CP) paradigm that had been developed by Mason $(1939,1959)$ and Bain $(1951,1956)$; these studies were at the forefront of the efforts to determine whether firms in high-concentration (oligopoly) industries were exercising market power - as would be indicated by comparatively high profit rates in those industries. It was clear that there needed to be some correction for the riskiness of an industry, since risk would likely be an influence on what was considered to be a "normal" (or competitive) rate of return in the industry. And the CAPM indicated that this measure of risk should be a covariance measure rather than a simple variance measure.

A few empirical studies in the 1960s and 1970s (e.g., Hurdle, 1974) did include a risk measure (though not always a covariance measure) as an explanatory variable in those profitconcentration regressions. But the 1970s were the "last hurrah" for these kinds of studies: The accounting measures of profitability that were the standard left-hand-side (LHS) variable for these studies came under close scrutiny and intense criticism, as did the issue of whether high profitability (even if measured properly) would necessarily be an indicator of the exercise of market power (e.g., Demsetz, 1974; Mancke, 1974). These kinds of studies fell out of fashion in 
IO by the early 1980s, ${ }^{1}$ and with them went the covariance-of-profitability measures that were based on the CAPM.

Tobin's $Q$ as an indicator of market power

Tobin (1969) developed his “Q” measure - the ratio of the aggregate market value of a firm's assets divided by the reproduction cost of those assets - in the late 1960s primarily as a macroeconomic tool: If the value of $\mathrm{Q}$ for a major firm in a sector (or the sector itself) exceeds 1.0, firms should find it worthwhile to expand their investments in that sector, since the returns should exceed the costs.

In the early 1980s Lindenberg and Ross (1981) suggested that Q could also be considered to be an indicator of the above-normal profits that could arise from the exercise of market power and thus ought to be positively correlated with seller concentration, which appeared to be the case. However, it was also clear that there were important other reasons for Q to exceed 1.0: For example, the market value numerator would surely include the value of intellectual property and of the value of brand-based goodwill, both of which would likely be poorly represented in the reproduction cost denominator, which was usually based on balance sheet data that tended to not include or under-represent such "intangible” assets. Further, the criticism of accounting measures of profit that eroded confidence in the profit-concentration studies extended to the skepticism of balance sheet data more generally as good measures of the reproduction costs of the firm (at least partially because of the intellectual property and branding issues that were just mentioned).

Consequently, studies that use Q as an indicator of market power have, like the profitconcentration studies, fallen by the wayside since the 1980s.

Event studies that would help ascertain whether a merger would be anticompetitive 
Event studies have been a staple in empirical finance (and empirical accounting) since the late 1960s (e.g., Kothari and Warner, 2007). The basic idea is that the market's reaction to a firm's announcement of an unanticipated event - say, a proposed merger - should be an indicator of the market's expectations as to the consequences for the firm's future profitability from that event. $^{2}$ And those expectations ought (on average) to be a good predictor of that future profitability, since if systematic biases in the way that the market reacted to such announcements were otherwise to be present, smart arbitrageurs ought to be able to exploit such systematic biases until those biases disappeared. (This "efficient markets" hypothesis/insight was another important intellectual development in the finance field in the late 1960s and early 1970s.) In the early 1980s Baxter (1980) first proposed that the event study methodology might be used in the antitrust analysis of mergers. He argued that the crucial focus should be on the competitors/rivals to the merging firms. The S-C-P paradigm indicated that a merger that would be anticompetitive would do so by increasing seller concentration (in a relevant market) sufficiently that the firms in the market would (because of enhanced recognition of their mutual interdependence) reduce the intensity of their competition and thus be able jointly to raise their prices. ${ }^{3}$ In this context, if the consequences of the merger were anticipated to be anticompetitive, then the non-merging rivals to the merging firms ought to be (along with the merged firm) the beneficiaries of the higher industry-wide prices that would follow from the merger. By contrast, if the primary effect of the merger was to reduce the costs of the merging firm (and have little or no effect on oligopolistic coordination), then the non-merging rivals would be at a disadvantage as a consequence of the merger.

Consequently, event studies that focused on the market reactions of the rivals' share prices (and returns) ought to be able to determine of the nature of the merger for antitrust 
purposes: If the merger would likely be anticompetitive, then the event studies should yield a positive abnormal return for the rivals' shares; if, instead, the merger was expected primarily to reduce the merged firm's costs, then the event studies should yield negative abnormal returns for the rivals' shares. And, of course, if a merger were neutral, with neither market power nor costefficiency consequences, then the event studies should yield little or no abnormal returns for the rivals.

However, even if the merger were cost-reducing, event studies might show positive abnormal returns for the rivals' share prices, because the merger might awaken the market to the possibilities of cost-reducing mergers by the other firms in that market; and, equally contrarily, if the merger were to increase seller concentration and also affect vertical relationships with suppliers and/or customers in ways that would disadvantage the rival firms, the event studies might show negative abnormal returns for their share prices despite the increased seller concentration and likely higher prices. Also, if the rivals weren't publicly traded companies, event studies wouldn’t be possible. And if the rivals were multi-product (and/or multi-area) companies and the relevant market for the merger accounted for only small fractions of the rivals' profits, the event studies might yield little or no reactions because the profits at stake would be lost in the noise.

Consequently, after an initial flurry of interest in the early 1980s (e.g., Eckbo, 1983; Eckbo and Wier, 1985), there has been little subsequent use of event studies to examine the reactions of rivals' share prices in antitrust merger analysis.

I am unaware of other major efforts to bring major elements of finance into IO since then.

\section{Why the quest is likely to be futile}


The history that has just been recounted does not offer great hope for greater integration of finance into IO. And this pessimism is warranted. After all, finance and IO are two major but separate specialty fields/disciplines within the broader field of economics. Each discipline has its specialized courses that graduate students take during their Ph.D. studies. Each has its own core theory and its own core empirical methods and frequently used data sets. Few IO economists are familiar with the major issues of finance; few finance economists are familiar with the major issues of $\mathrm{IO}^{4}$

This separation was driven home to me a decade ago, when I co-authored a survey paper “Empirical Studies of Financial Innovation: Mostly Talk and Not Much Action?” (Frame and White, 2004). What was striking to us were three contrasts: The first was the sharp contrast (which motivated our paper) between the broad generalizations within the finance field about how important financial innovation had been and how little effort there had been actually to do any empirical testing of hypotheses that might help advance the profession's understanding of the processes of financial innovation. The second contrast was between this paucity of empirical studies of financial innovation and the far greater number of empirical IO studies of innovation in manufacturing and in many other sectors of the economy (but largely bypassing financial services). And the third contrast was between the emphasis of the (comparatively few) empirical studies of financial innovation on the study of the characteristics of early adopters (often through diffusion studies) and the relative absence of an interest in the issues of how and why financial innovation occurred - which, at least since Schumpeter (1950), has been a major theme of empirical IO investigations of innovation (along with, of course, adoption/diffusion studies).

In thinking about these contrasts, Frame and I offered two tentative hypotheses to explain them: First, the standard data sets that finance economists (especially in the U.S.) often work 
with - the Center for Research in Securities Prices (CRSP) data files and Standard \& Poor's COMPUSTAT data files - are ill suited to uncovering any information about innovation. By contrast, IO economists (especially in the U.S.) that are interested in innovation have traditionally been able to access annual patent data and annual research and development (R\&D) data - with detailed industrial classifications and even firm-level identification often available for both data sets. And for neither the patent data nor the R\&D data has innovation activity by firms in the financial services areas been especially well represented.

Second, IO economists were unlikely to venture deeply into the finance area to study financial innovation, because they weren't well trained in finance, so the basic ideas and basic institutions would mostly be foreign - except for diffusion studies, where adoption decisions (especially for automated teller machines [ATMs], which have been extensively studied) could be readily identified and hypotheses concerning the characteristics of potential adopters could be readily tested. And finance economists had not been trained to think about innovation from an IO perspective, so that Schumpeter has been rarely mentioned by the finance economists who have written about financial innovation and concepts such as “appropriability” and “technological opportunity” are rarely mentioned as well.

In sum, the two fields were and remain separate; substantially closer integration is unlikely to occur.

\section{Conclusion}

Although the goal of a major integration of finance into IO (or vice-versa) is a chimera, there are nevertheless at least two places where the two disciplines can usefully overlap. First, as is true across the spectrum of industries in an economy, IO tools can be used to address IO 
questions within the financial sector (e.g., S-C-P questions; efforts to explain specific pricing and other behavioral practices; innovation questions; etc.); of course, as should be true for any such study, the IO economists that conduct such studies should have enough understanding of the specific industry and its institutional detail that they can "get it right”. Second, event studies can continue to be useful for providing an indication of the impact of legal or regulatory changes on firms or industries (e.g., Garbade, Silber, and White, 1982).

These are more modest targets for the interaction of the two disciplines. But they are more realistic as well.

\section{References}

Bain, Joe S. 1951. Relation of Profit Rate to Industry Concentration: American Manufacturing. 1936-1940. Quarterly Journal of Economics 65 (3): 293-324.

Bain, Joe S. 1956. Barriers to New Competition (Cambridge, MA: Harvard University Press).

Baxter, William F. 1980. The Political Economy of Antitrust. (Lexington, MA: Lexington Books).

Demsetz, Harold. 1974. Two Systems of Belief about Monopoly, in: Harvey J. Goldschmid, H. Michael Mann, and J. Fred Weston (Eds.), Industrial Concentration: The New Learning, pp. 164-183 (New York: Columbia University Press).

Eckbo, B. Espen. 1983. Horizontal Mergers, Collusion, and Stockholder Wealth. Journal of Financial Economics 11 (1-4): 241-273.

Eckbo, B. Espen and Wier, Peggy. 1985. Antimerger Policy under the Hart-Scott-Rodino Act: A Reexamination of the Market Power Hypothesis. Journal of Law and Economics 28 (1): 119149.

Frame, W. Scott and White, Lawrence J. 2004. Empirical Studies of Financial Innovation: Lots of Talk, Little Action? Journal of Economic Literature 42 (1): 116-144.

Garbade, Kenneth D., Silber, William L., and White, Lawrence J. 1982. Market Reaction to the Filing of Antitrust Suits: An Aggregate and Cross-Sectional Analysis. Review of Economics and Statistics 64 (4): 686-691. 
Hurdle, Gloria J. 1974. Market Structure and Profitability. Review of Economics and Statistics 56 (4): 478-485.

Kothari, S.P. and Warner, Jerold B. 2007. Econometrics of Event Studies, in: B. Espen Eckbo (Ed.), Handbook of Corporate Finance: Empirical Corporate Finance, pp. 3-36 (Amsterdam: Elsevier).

Lindenberg, Eric B. and Ross, Stephen A. 1981. Tobin’s Q Ratio and Industrial Organization. Journal of Business 54 (1): 1-32.

Mancke, Richard B. 1974. Causes of Interfirm Profitability Differences: A New Interpretation of the Evidence. Quarterly Journal of Economics 88 (2): 181-193.

Mason, Edward S. 1939. Price and Production Policies of Large-Scale Enterprise. American Economic Review 1939 (1): 61-74.

Mason, Edward S. 1959. Economic Concentration and the Monopoly Problem (Cambridge, MA: Harvard University Press).

Schumpeter, Joseph A. 1950. Capitalism, Socialism, and Democracy, $3^{\text {rd }}$ edn. (New York: Harper \& Bros.).

Tobin, James. 1969. A General Equilibrium Approach to Monetary Theory. Journal of Money, Credit and Banking 1 (1): 15-29.

\footnotetext{
${ }^{1}$ They were largely replaced by efforts to use price as the LHS variable in cross-section regressions for industries where local markets (and local levels of concentration) could be identified.

${ }^{2}$ Specifically, such a study would first establish a baseline (during an immediately preceding period of, say, 60 or 90 days) of how the daily stock returns varied with the daily returns of the overall market (again making use of the insights of the CAPM). Then, for a period shortly before the announcement (in case there had been an earlier leakage of the news) until shortly after the event (because the market would be expected quickly to reassess the firm's future profitability prospects in light of the event) the daily returns for the firm would be compared to the expected daily returns for that firm given the overall market's daily returns during that event "window" and the expected covariance of the firm with the market (as distilled from the baseline results). A significant deviation from the expected return is dubbed an "abnormal" return.

${ }^{3}$ In the language of merger analysis of the 1990s and afterward, this was a "coordinated effects" theory of the potential anticompetitive effects of a merger. The "unilateral effects" theory would also predict that the rivals would be beneficiaries of an anticompetitive merger.

${ }^{4}$ There are exceptions: The Federal Reserve research staff has had a long tradition of hiring IO economists who either came to the Board of Governors with some understanding of finance or who acquired it through on-the-job training; and the 12 regional Federal Reserve banks have had a similar tradition. Also, there are a few academic economists - mostly in business schools - who have become proficient in both fields. Still, these are the exceptions.
} 